\title{
OIL PROBLEM IN THE USSR
}

\author{
Hiromasa NAKAYAMA \\ (Meiji Gakuin Univ.)
}

We are aware of the major role played by petroleum in modern civilization. We can hardly live even a day without it.

In Japan, in 1955 , petroleum occupied only a $20 \%$ share in the first stage of energy supply. But it grew to $70 \%$ by 1970 . In the meantime, the percentage of coal usage has fallen from $21 \%$ to $6.3 \%{ }^{1}$ The contrast is very clear. But petroleum has been imported very cheaply because of the strength of the socalled "Majors", thus the real value of petroleum was not recognized in our country prior to the "Oil Shock". The action of OPEC forced the world, especially industrially developed countries, to recognize this real value of petroleum and its producer countries.

As a consequence of the "Oil Shock", the petroleum of the USSR began to attract public attention. Her petroleum supplies $50 \%$ of energy of her own country (coal supplying about 25\%). But, since the "Oil Shock", the USSR has furnished not only her own country but also the world market with a growing amount of petroleum. In this article, I attempt to analyse the oil problem of the USSR which has developed out of this situation.

\section{History}

Imperial Russia was once the largest oil producing country in the world. Leadership in the oil industry was soon taken by other nations as in the ironsteel industry, coal, and electricity, but in the 1890's Russia led the world in oil production. During this period of industrialization under Finance Minister Witte, the number of oil wells grew from 500 to 1500 , then to 2000 . At the

1. Kokumin no Dokusen Hakusho, Sekiyu, Ochanomizu Shobo, 1981, p. 24. 
HIROMASA NAKAYAMA

Table 1 Production and export of oil and others of the USSR

\begin{tabular}{|c|c|c|c|c|c|c|}
\hline \multirow{2}{*}{ Year } & \multicolumn{2}{|c|}{ Oil } & \multirow{2}{*}{$\begin{array}{l}\text { Natural gas } \\
\text { extracted } \\
\text { (billion } \mathrm{M}^{3} \text { ) }\end{array}$} & \multirow{2}{*}{$\begin{array}{c}\text { Fuel, electric } \\
\text { power } \\
\text { (\% to the } \\
\text { total export) }\end{array}$} & \multirow{2}{*}{$\begin{array}{l}\text { of it oil } \\
(\%)\end{array}$} & \multirow{2}{*}{$\begin{array}{l}\text { Machines, } \\
\text { equipment } \\
\text { (\% to the } \\
\text { total export) }\end{array}$} \\
\hline & $\begin{array}{c}\text { Crude } \\
\text { oil (m.t.) }\end{array}$ & Export & & & & \\
\hline 1913 & 9.2 & & - & & & \\
\hline $1922 / 23$ & 10.3 & & - & 7.8 & 7.8 & \\
\hline 1928 & 11.6 & & 0.3 & & & \\
\hline 1932 & 21.4 & & 1.0 & & & \\
\hline 1937 & 28.5 & & 2.2 & & & \\
\hline 1940 & 31.1 & & 3.2 & 13.2 & 13.1 & \\
\hline 1950 & & & & 3.9 & 2.4 & \\
\hline 1955 & 70.8 & & 9.0 & 9.6 & & 17.5 \\
\hline 1958 & & & & 15.2 & & 18.5 \\
\hline 1959 & & & & 14.7 & & 21.5 \\
\hline 1960 & 147.9 & & 45.3 & 16.2 & 11.9 & 20.5 \\
\hline 1961 & & & & 17.5 & & 16.1 \\
\hline 1962 & & & & 16.5 & & 16.6 \\
\hline 1963 & & & & 17.9 & 12.5 & 19.7 \\
\hline 1964 & & & & 17.7 & 12.3 & 21.0 \\
\hline 1965 & 242.9 & 64.4 & 127.7 & 16.8 & 12.2 & 20.0 \\
\hline 1966 & 265.1 & 73.6 & 143.0 & 16.0 & 12.0 & 20.8 \\
\hline 1967 & 288.1 & 78.8 & 157.4 & 15.6 & 12.0 & 21.1 \\
\hline 1968 & 309.2 & 86.2 & 169.1 & 16.1 & 12.3 & 21.6 \\
\hline 1969 & 328.4 & 90.8 & 181.1 & 15.7 & 11.8 & 22.5 \\
\hline 1970 & 353.0 & 95.8 & 197.9 & 15.5 & 11.5 & 21.5 \\
\hline 1971 & 377.1 & 105.1 & 212.4 & 18.0 & 13.3 & 21.8 \\
\hline 1972 & 400.4 & 107.0 & 221.4 & 17.4 & 13.0 & 23.6 \\
\hline 1973 & 429.0 & 118.3 & 236.3 & 18.5 & 15.8 & 21.8 \\
\hline 1974 & 458.9 & 116.2 & 260.6 & 24.7 & 22.0 & 19.2 \\
\hline 1975 & 490.8 & 130.4 & 289.3 & 31.4 & 24.6 & 18.7 \\
\hline 1976 & 519.7 & 148.5 & 321.0 & 34.3 & 27.4 & 19.4 \\
\hline 1977 & 545.8 & 155.9 & 346.0 & 35.1 & 28.3 & 18.8 \\
\hline 1978 & 571.5 & & 372.2 & 35.6 & 28.1 & 19.6 \\
\hline 1979 & 585.6 & & 406.6 & 42.1 & 34.2 & 17.5 \\
\hline 1980 & 603.2 & & 435.2 & 46.8 & 36.4 & 15.8 \\
\hline 1981 & & & & 50.1 & 37.8 & 13.7 \\
\hline
\end{tabular}

Narodnoe Khoziaistvo USSR, every year.

Vneshnyaya Targovlya USSR, every year. 


\section{OIL PROBLEM IN THE USSR}

same time the production of oil grew from 4 million tons to 11.47 million tons, that was 3 million more than the US production of the day. But in the first years of 1900 , oil production reached its peak and after that, with the crisis of 1900-1902, oil production fell. In the year before World War I, it again grew slowly, but its level was now only 9.20 million tons. The export of "Oil of Russia", once near 2 million tons, also fell.

With the USSR's decline, the USA moved into first place in oil production. However, the USSR again took first position from the middle of the 1970's, after the "Oil Shock".

The level of petroleum production, which had fallen with the Russian revolution and the civil war, again reached the pre-revolutionary level by 1928-11.625 million tons-when the first Five Year Plan was instituted. (Table 1) In 1932, production reached 21.414 million tons, doubling in 5 years. By 1937, it grew to 28.50 million tons and to 31.10 million tons in 1940, which was almost the same level as the USA before World War I. Thus there was a time lag of about 26 years.

In 1955, just when Japan began its High Rate of Economic Growth, the USSR produced 70.80 million tons of petroleum from its own territory. This was about one tenth of total world production. According to Soviet statistics, in comparison with the US oil production, the USSR production was $14 \%$ of the USA in 1950 , and then $42 \%$ in $1960,74 \%$ in 1970 , and lastly $140 \%$ in $1980 .^{2}$

In its balance of trade USSR exports of oil occupied only $7.8 \%$ of total exports in the beginning of the NEP era (in 1922/23), which gradually grew to $13.1 \%$ by the Second World War in 1940. (Table 1) After the War, this percentage fell to $2.4 \%$ in 1950 , because other commodities especially machines and equipments grew more rapidly. But export of petroleum again steadily began to grow during the 1950's. It reached $11.9 \%$ in $1960,16.2 \%$ including other fuels and electric energy, and then it stabilized at a level of $12 \%$ of the total exports during the 1960's.

2. Narodnoe Khoziaistvo USSR in 1980, p. 59. 


\section{The Production and Trade of Oil in Contemporary USSR}

The oil production of the USSR jumped during the 1960's, at a surprising pace and more than doubled. This reflected a world wide trend, because 1961-1981 world oil production accounted for 73.3\% of total oil production of the world up to that time. In the case of the USSR, $82.0 \%$ of its oil was produced during this 1961-1981 period. $^{3}$ It jumped from 147.90 million tons in 1960 , to 353.0 million tons in 1970 . At the same time production of natural gas jumped from 45.3 billion $\mathrm{M}^{3}$ to 197.9 billion $\mathrm{M}^{3}$, this was nearly four times. The USSR also experienced a period of "High Economic Growth" similar to Japan, from 1955 to 1965 , with oil production tripling and natural gas quadrupling. This high pace of economic growth encouraged Khrushchef to manifest the "Peaceful Coexistence of the two systems (Communist and Capitalist) and the future Triumph of Socialism in economic competition". His slogan widely known "to overtake USA, and outrun it" seemed reasonable at the time.

In fact, however, this slogan was not achieved in the USSR's total industrial and economic output, but only for oil, which was achieved during the 1970's under Brezhnev. During the 1970's, including the Oil Shock of 1973 , oil production of the USSR succeeded in maintaining high growth. It doubled by jumping from 353 million tons in 1970 to 603.2 million tons in 1980. Production of natural gas during this same period grew from 197.9 billion $\mathrm{M}^{3}$ to 435.3 billion $\mathrm{M}^{3}$. This was also a doubling. We can say without hesitation that this high pace of economic growth is a very surprising development in the economic history of humankind. Because of this high pace of growth in oil production, the CIA of the USA estimated that 1977 would be the turning point for USSR from being an oil exporting country to that of an importing one. The oil production of USSR, however, continued to grow and grow, so that the CIA had to modify its estimate to a later date. Yet this kind of high-speed production contains many problems, to which we shall return at a later point afterwards. At present we shall focus our attention upon the fact that a rather high percentage of this oil production has been

3. Planovoe Khoziaistvo, 1983-8, G. Merlin. 


\section{OIL PROBLEM IN THE USSR}

turned to exports, especially following the oil shock. Specifically, the percentage occupied by oil in the total export of the USSR rose almost abruptly to $20 \%$ and in 1980 it occupied the high figure of $36.4 \%$. If we add other fuels and electric power, then this percentage rose from $15.5 \%$ in 1970 , to $24.7 \%$ in 1974 , and then to $50.1 \%$ in 1981 .

Under these conditions the percentage of machines and other heavy equipment exports which reached about 20\% in the last half of the 1960's and $23.6 \%$ in 1972 (before the Oil Shock) fell to $13.7 \%$ in 1981 . This level was nearly that of 1955 levels. The USSR long boasted of the high percentage of these items (machines and heavy equipment), insisting that it reflected the high level of its industrialization. But it turned out that its share of oil was growing and that of machines and equipment was becoming smaller. Ironically, the USSR fell from being a strong high developped industrial country to that of a raw material exporting country, i.e. a "one crop export country". 4 Of course here the word "crop" is used symbolically meaning non-manufactured goods. It is widely known that real agricultural crops are also now a major trade commodity in the USSR. This agricultural problem is not a theme in this paper, but it is a very serious matter that oil and other fuel exports from the USSR exceeded 50\% in its 1981 balance of trade, and that she fell to an underdevelopped status of "one crop exports", from which Imperial Russia had so long suffered.

The actual situation for the USSR is more serious and complex. Up to this point we have mentioned only the percentages and structure of its balance of trade, but it is widely known that USSR balance of trade in reality consists of two different currencies-the Soviet rouble and so-called "hard currency". A further reason that makes analysis difficult is that the balance of paymentswhich of course includes not only the balance of trade but also the movement of capital and gains, aid and gifts etc.-of the USSR is kept secret and not made public under the Soviet Regime. This is not different from the imperial Russian Era when the balance of payments was not published. If we take a look only at the area of hard-currency (US dollars, Marks, Yen, etc.) the USSR has long been in the red (deficit) including the 1970's because of the

4. Marshall I. Goldman, The Enigma of Soviet Petroleum. Half-Full or Half-Empty? 1980, p. 91. 
large imports of grain during these years. Of course the USSR itself does not publish this data concerning hard-currency, but this information comes from the evaluations of the CIA. According to this, USSR imports in hard currency grew from 8.5 billion US dollars in $1974,14.3$ billion in 1975 , to $15-16$ billion after that, while USSR exports grew from 7.8-9.7 billion to 11-13 billion, causing the balance to be nearly in the red. ${ }^{5}$ of course, these speculations of the CIA can not be relied upon totally, because their speculations of the total balance of payments also include the export of arms and gold. Notwithstanding this we can surmize that the growth of USSR oil exports hardly covered the balance of trade in hard currency terms.

Strictly speaking, all exports of oil do not earn hard currency, because about $40-50 \%$ of oil exports are oriented to communist countries. Even after the Oil Shock, $40-50 \%$ of oil exports have been continually supplied to DDR, Czechoslovakia, Poland, Bulgaria, and Yugoslavia. Even with the "Solidarity" movement in Poland, the oil supply from the USSR did not decrease, but rather stabilized. Other buyers (demander) of USSR oil, primarily western countries, pay in hard currency. The export of oil to communist countries does not bring in hard currency. More over, the price of oil to these countries is cheaper than that of oil to the western countries even after the Oil Shock.

Western analysis estimates that the level of energy self-sufficiency in the Eastern European Countries decreased from 99\% in 1960 to $68 \%$ by 1979. The structure of energy consumption differs in the Eastern European Countries from Western European countries and Japan, for Eastern Europe relies more heavily upon coals than the west. ${ }^{6}$

Table 2

\begin{tabular}{|l|c|c|c|}
\hline & $\frac{\text { Eastern europe }}{(1977)}$ & $\frac{\text { Japan }}{(1978)}$ & $\frac{\text { Western europe }}{(1977)}$ \\
\hline Oil & 29 & 72 & 55 \\
Coal & 49 & 14 & 20 \\
Natural gas & 17 & 5 & 14 \\
Electric power & 5 & 9 & 11 \\
\hline
\end{tabular}

5. Joint Economic Committee of the Congress of the United States, Soviet Economy in a Time of Change, 1979, 10. vol. 2, p. 212.

6. Kokusai Shigen, 1980-8, p. 50. 


\section{OIL PROBLEM IN THE USSR}

Eastern Europe relies less on oil, although oil demand has gone up from $13 \%$ in 1960 to $29 \%$ in 1977 . These percentages of course vary from country to country. In 1977, Bulgaria gained from oil $70 \%$ of its first step energy, Hungary 44\%, Czechoslovakia 35\%, DDR 28\%, Poland 15\%, and Romania $2 \%$. The problems of oil prices will be analysed later.

\section{Challenge of OPEC and USSR Oil}

Thus far we have followed the process of oil production growth in the USSR particularly after the Oil Shock, and we found that its growth had nearly changed the basic structure of the USSR's balance of trade. This growth of production and export of USSR oil had an undesirable influence upon both OPEC and the USSR itself. When OPEC suddenly raised its price of oil in 1973 , it shared $54.8 \%$ of total world oil production. It thus had a great influence on the world oil market. But after the considerable increase in prices, non-OPEC countries, such as England (North Sea Oil Field), Mexico, and USSR, rushed to produce more oil at these higher prices. The OPEC share in the world market fell below 50\%, and by 1982, it occupied only $35.1 \%$ of world production. Non-OPEC, Non-Communist Countries accounted for $37.3 \%$ while Communist Countries $27.6 \%$ of which the USSR provided 23\%. (Table 3) The OPEC share fell from $1 / 2$ to $1 / 3$. Not long after, OPEC oil Production roughly equaled that of the Communist Countries. However, concerning this decreasing OPEC share, we must take into account other factors as well. After the Oil Shock, total demand for oil in

Table 3 World crude oil production

\begin{tabular}{|c|c|c|c|c|c|c|c|c|}
\hline \multirow{4}{*}{$\begin{array}{l}\text { World total } \\
\text { OPEC } \\
\text { non-OPEC }\end{array}$} & \multicolumn{2}{|c|}{$\frac{1974}{\text { Production (\%) }}$} & \multicolumn{2}{|c|}{$\frac{1979}{\text { Production (\%) }}$} & \multicolumn{2}{|c|}{$\frac{1982}{\text { Production (\%) }}$} & \multicolumn{2}{|c|}{$\frac{1983 \text { (I Fourth) }}{\text { Production (\%) }}$} \\
\hline & 55,925 & 100.0 & 62,812 & 100.0 & 53,191 & 100.0 & 50,263 & 100.0 \\
\hline & 30,656 & 54.8 & 30.826 & 49.1 & 18,661 & 35.1 & 15,036 & 29.9 \\
\hline & 14,500 & 25.9 & 17,759 & 28.3 & 19,825 & 37.3 & 20,276 & 40.4 \\
\hline $\begin{array}{l}\text { Communist. } \\
\text { area }\end{array}$ & 10,769 & 19.3 & 14,227 & 22.6 & 14,705 & 27.6 & 14,951 & 29.7 \\
\hline
\end{tabular}

Naoshi KOJIMA, A Challenge of OPEC. "Contemporary International Economics" (in Japanese), 1984. Tokyo University Press. p. 112. 
HIROMASA NAKAYAMA

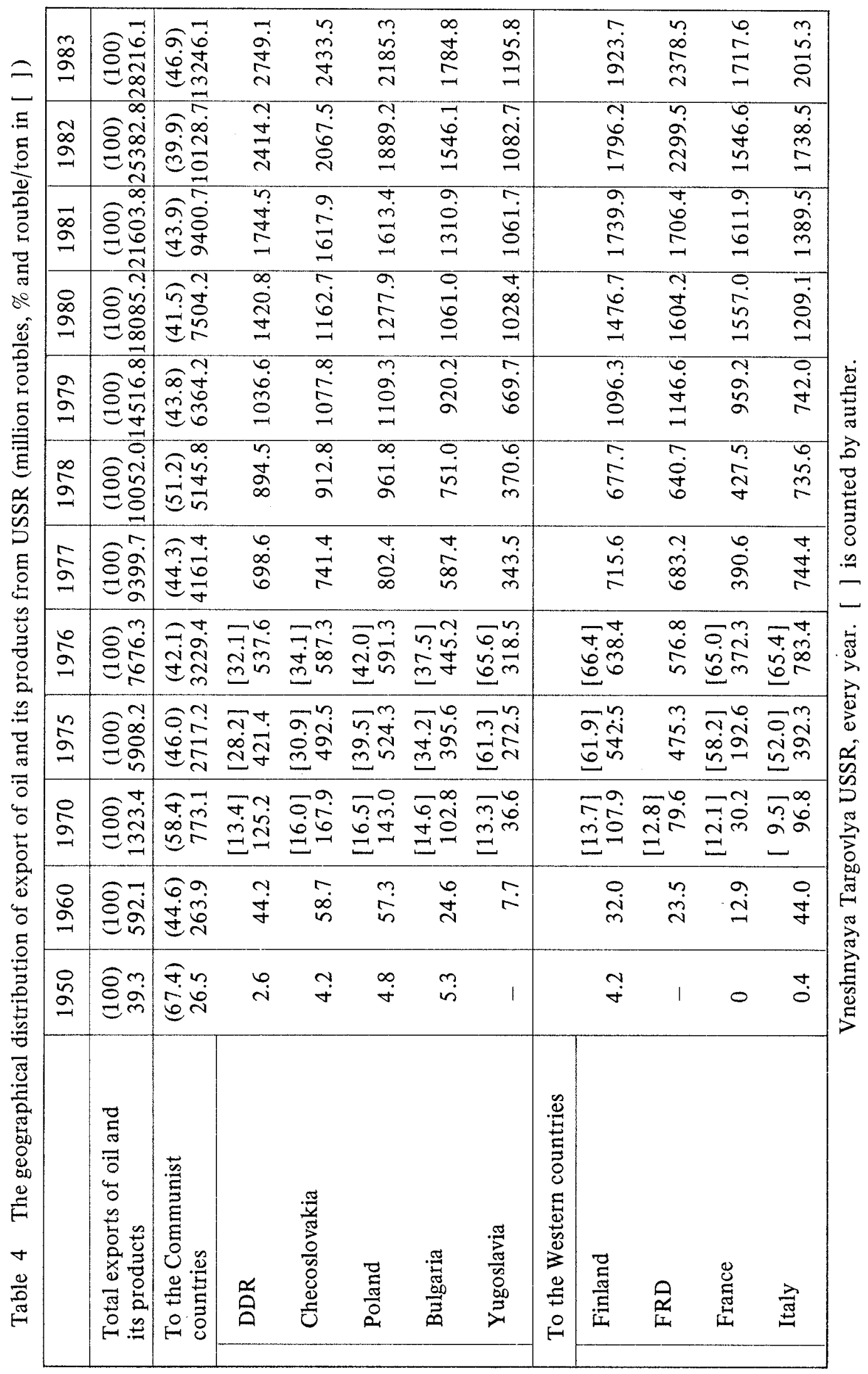


the world began to decrease. For example the total world demand for oil was $51.6 \mathrm{M} \mathrm{b}$ /day in 1979 , but it was only $45.5 \mathrm{M} \mathrm{b} / \mathrm{d}$ in 1982 (a $12 \%$ drop in demand). This together with the increase of USSR oil production caused a decrease the price of oil. Following the first Oil Shock it jumped from 3 dollars/b to $11.7 \mathrm{~d} / \mathrm{b}$ and from $13 \mathrm{~d} / \mathrm{b}$ to $32 \mathrm{~d} / \mathrm{b}$ after the second Oil Shock in 1980. The USSR together with non-OPEC oil producing countries inflicted considerable damage to the OPEC countries and then she hurted herself also. "The USSR exported $3 \mathrm{M} \mathrm{b} / \mathrm{d}$, of which $2 \mathrm{M}$ b/d were exported to Communist Countries (1.6 $\mathrm{M} \mathrm{b} / \mathrm{d}$ to Eastern Europe), and $1 \mathrm{M} \mathrm{b} / \mathrm{d}$ was exported to the free World in order to gain much needed hard currency. But, in 1982, the price of USSR oil had to be reduced as was the case for non-OPEC oil producing countries. The USSR was forced to increase export of oil to the Western countries to $1.5 \mathrm{M} \mathrm{b} / \mathrm{d}$ perhaps even to $2 \mathrm{M} \mathrm{b} / \mathrm{d}$ and decreased her exports to Eastern countries at the same time. This was prompted by the necessity to gain hard currency."7

We now turn our attention to an analysis of the price of exported USSR oil. (Table 4) Mr. Kiyoshi SHITARA has stated "The price of USSR oil exported to Eastern countries is determined on the basis of a 5 year average of international prices, considering also in 1975 changes in the decision making structures of COMECON countries. As a result, the price of USSR oil exports to the Eastern countries slowly increased from 40 dollars/ton in 1976 to 70 and more/ton in 1980 (about 15 dollars/b), although it had long been only one fourth of the international price level. This is of course very cheap in comparison with the OPEC standard export price of 32 dollars/b-But it is said that payment on oil in excess of the longterm contact must be paid for by hard currency and according to international prices. These advances in the price of USSR oil have been faster than the advance of the prices of export commodities from Eastern European Countries to USSR. Thus the economic burden upon these countries has grow considerably." 8

This was the situation in 1980 , while the situation in 1984 is a little dif-

7. Sekai Shuho, 1983. 4. 26, Koichi HASEGAWA, "USSR exported 1.5 M.b./d. and gained 17.5 billion dollars in hard currency." Sekai Shuho, 1983. 3. 22, Toshiaki USHIJIMA.

8. Kokusai Shigen, 1980-8, Kiyoshi SHITARA. 
ferent, it is certain that the Eastern countries can no longer import cheap oil from the USSR as was the case before the Oil Shocks. Thus far the USSR has succeeded to offer a volume of cheap oil and other forms of energy to the Eastern European Countries and thereby continuing to maintain these countries within its own economical and political influence. In general, these countries are poor with anxiety mounting over their 33 billion dollars in debts to the West, (cheap energy from the USSR has been a very important factor to their governments). But now as the USSR itself has been forced to seek further hard currency, relations with these nations have also begun to undergo change.

As table 4 indicates, the price of USSR export oil before the Oil Shock in 1973, was at a very low level, between $3-4$ dollars/b (15-16 rouble/ton). This shows no difference between East and West. Since the year 1975 and 1976 came after the Oil Shock, prices to the Western countries advanced 4.5 times to 13-14 dollars/b and with it prices to the Eastern countries advanced about twice. We can not give an account after 1977 because the USSR stopped making public some of the real figures in their statistics including those for oil. But we already indicated prices to the Eastern European Countries have risen to 70 roubles and more.

\section{Present Situation of the Petroleum Industry in the USSR and its Perspective}

Thus far we have investigated the problem of the petroleum industry in the USSR mainly in the area of international trade and that of production in so far as it has relation to trade. Here we want to examine the USSR oil industry itself. We want to see how the USSR is able to continue to produce petroleum at the same pace as it has done. According to the 11th Five Year Plan (1981-1985) the USSR planned to produce only 620-645 million tons of oil in 1985, which would be $3-7 \%$ more than the 603 million tons produced in 1980. Of course these numbers themselves are very large and it may not seem suitable to use the word "only", but the percentage (3-7\%) is lower than many Five Years Plans during the 1960's and 1970's. It is certainly lower in comparison with other sources of energy. For example, natural gas is planned 
to increase from 435 billion $\mathrm{M}^{3}$ in 1980 to $600-640$ billion $\mathrm{M}^{3}$ in 1985 (38$47 \%$ ), electric power from 1295 billion KWh in 1980 to $1550-1600$ billion KWh in 1985 (20-24\%), and even coal from 716.4 million tons in 1980 to $770-800$ million tons in 1985 (7-12\%).

It is well known that the rate of economic growth decreased during the 1970's, particularly the last half of the 70's. As a result, if the production of petroleum in the USSR is approaching its limit, this will be very serious not only for the rate of growth of the USSR, but also for the economics and politics of the entire modern world. Thus we must ask, what is the real situation of the oil industry in the USSR? In order to answer this problem, we must first examine the present statistics of "the National Economy in the USSR".

Table 5 Fundamental investments to the various department of industries USSR (billion roubles, \%)

\begin{tabular}{|c|c|c|c|c|}
\hline & $\begin{array}{c}1966-1970 \\
(8 \text { th FYP) }\end{array}$ & $\begin{array}{c}1971-1975 \\
(9 \text { th FYP) }\end{array}$ & $\begin{array}{l}1976-1980 \\
\text { (10th FYP) }\end{array}$ & in it 1980 \\
\hline Industry total & $119.7(100.0)$ & $168.7(100.0)$ & $219.4(100.0)$ & $46.5(100.0)$ \\
\hline Electric power & $13.6(11.4)$ & $17.0(10.1)$ & $19.4(8.8)$ & $4.2(9.0)$ \\
\hline Coal & $7.2(6.1)$ & $8.3(4.9)$ & $9.8(4.5)$ & $2.1(4.5)$ \\
\hline Oil & $11.1(9.2)$ & $16.0(9.5)$ & $26.2(12.0)$ & $6.6(14.3)$ \\
\hline Natural gas & $4.5(3.7)$ & $7.3(4.3)$ & $10.3(4.7)$ & $2.2(4.7)$ \\
\hline in Metallurgy & $9.9(8.3)$ & $12.9(7.6)$ & $15.2(6.9)$ & $3.1(6.6)$ \\
\hline it $\begin{array}{l}\text { Chemistry, } \\
\text { petro-chemi. }\end{array}$ & $11.0(9.2)$ & $15.6(9.3)$ & $22.2(10.1)$ & $4.0(8.6)$ \\
\hline $\begin{array}{l}\text { Mashine, metal } \\
\text { manu. }\end{array}$ & $22.4(18.8)$ & $37.7(22.4)$ & $53.9(24.6)$ & $11.5(24.7)$ \\
\hline Lumber ind. & $4.0(3.3)$ & $5.4(3.2)$ & $5.9(2.7)$ & $1.2(2.5)$ \\
\hline Pulp & $1.8(1.5)$ & $2.4(1.4)$ & $3.2(1.5)$ & $0.5(1.2)$ \\
\hline $\begin{array}{l}\text { Materials for } \\
\text { construction }\end{array}$ & $6.3(5.3)$ & $8.5(5.0)$ & $9.2(4.2)$ & 1.9 \\
\hline Light ind. & $5.3(4.4)$ & $7.0(4.2)$ & 8.5( & 1.8( \\
\hline Foods ind. & $9.3(7.8)$ & $11.6(6.9)$ & $13.4(6.1)$ & 2.8 \\
\hline
\end{tabular}

Narodnoe Khoziaistvo USSR in 1980. Moscow. 1981. p.338

When we look at the statistics of investments for three Five Year Plans, we can readily see that the petroleum department occupies a very big share, second to that of the machine-metal department. Its share has grown steadily. 
HIROMASA NAKAYAMA

Table 6 Profits and profitability of the departments of industries USSR (million roubles, \%)

\begin{tabular}{|c|c|c|c|c|c|c|c|c|}
\hline & 1965 & 1970 & 1975 & 1976 & 1977 & 1978 & 1979 & 1980 \\
\hline Industry total & $\begin{array}{r}(10.6) \\
22548\end{array}$ & \begin{tabular}{|}
$(13.8)$ \\
55956
\end{tabular} & $\begin{array}{l}(15.8) \\
65941\end{array}$ & $\begin{array}{l}(15.9) \\
64827\end{array}$ & $\begin{array}{l}(15.9) \\
67161\end{array}$ & $\begin{array}{l}(15.6) \\
70659\end{array}$ & $\begin{array}{l}(14.6) \\
70346\end{array}$ & 73295 \\
\hline Electric power & $\begin{array}{l}(8.3) \\
875\end{array}$ & $\begin{array}{r}(8.4) \\
3464\end{array}$ & $\begin{array}{r}(7.8) \\
4341\end{array}$ & $\begin{array}{r}(8.0) \\
3904\end{array}$ & $\begin{array}{r}(7.8) \\
3999\end{array}$ & $\left(\begin{array}{r}8.1) \\
4322\end{array}\right)$ & $\left(\begin{array}{r}7.7 \\
4411\end{array}\right)$ & $\begin{array}{r}(7.8) \\
4637\end{array}$ \\
\hline Fuel & $\begin{array}{r}(13.2) \\
-614 \\
\end{array}$ & $\begin{array}{r}(13.9) \\
5229 \\
\end{array}$ & $\begin{array}{r}(12.3) \\
5461 \\
\end{array}$ & $\begin{array}{r}(11.6) \\
5636 \\
\end{array}$ & $\begin{array}{r}(10.7) \\
5428 \\
\end{array}$ & $\left(\begin{array}{r}9.3) \\
5025\end{array}\right.$ & $\begin{array}{r}7.4) \\
4400 \\
\end{array}$ & $\begin{array}{r}\left(\begin{array}{r}6.1) \\
4195\end{array}\right. \\
\end{array}$ \\
\hline Oil & $\begin{array}{r}(17.8) \\
311\end{array}$ & $\begin{array}{r}(21.9) \\
2380\end{array}$ & $\begin{array}{r}(16.8) \\
2553\end{array}$ & $\begin{array}{r}(15.2) \\
2551\end{array}$ & $\begin{array}{r}(13.4) \\
2532\end{array}$ & $\begin{array}{r}(11.6) \\
2284\end{array}$ & $\left(\begin{array}{r}9.1) \\
2014\end{array}\right.$ & $\begin{array}{r}\left(\begin{array}{r}7.5) \\
2162\end{array}\right.\end{array}$ \\
\hline Oil refining & $\begin{array}{r}(12.2) \\
568\end{array}$ & $\begin{array}{r}(15.8) \\
1165\end{array}$ & $\begin{array}{r}(23.3) \\
1785\end{array}$ & $\begin{array}{r}(23.2) \\
1937\end{array}$ & $\begin{array}{r}(24.2) \\
1995\end{array}$ & $\begin{array}{r}(25.1) \\
2263\end{array}$ & $\begin{array}{r}(23.8) \\
2358\end{array}$ & $\begin{array}{r}(23.5) \\
2451\end{array}$ \\
\hline in Natural gas & $\begin{array}{r}(56.5) \\
58\end{array}$ & $\begin{array}{r}(53.5) \\
747\end{array}$ & $\begin{array}{r}(22.7) \\
796\end{array}$ & $\begin{array}{r}(21.8) \\
916\end{array}$ & $\begin{array}{r}(20.9) \\
1014\end{array}$ & $\begin{array}{r}(18.7) \\
1062\end{array}$ & $\begin{array}{r}(17.6) \\
1161\end{array}$ & $\begin{array}{r}(16.0) \\
1198\end{array}$ \\
\hline Coal & $\begin{array}{r}(9.6) \\
-1582\end{array}$ & $\begin{array}{r}(4.4) \\
844\end{array}$ & $\begin{array}{l}(1.5) \\
242\end{array}$ & $\begin{array}{l}\left(\begin{array}{l}0.8) \\
148\end{array}\right.\end{array}$ & $\begin{array}{r}(-0.4) \\
-159\end{array}$ & $\begin{array}{l}(-2.8) \\
-626\end{array}$ & $\begin{array}{c}(-5.2) \\
-1155\end{array}$ & $\begin{array}{l}(-7.1) \\
-1638\end{array}$ \\
\hline Peat & $\begin{array}{r}(1.5) \\
8\end{array}$ & $\begin{array}{r}(4.0) \\
66 \\
\end{array}$ & $\begin{array}{r}(2.1) \\
29 \\
\end{array}$ & $\begin{array}{r}(3.1) \\
31 \\
\end{array}$ & 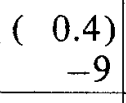 & 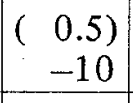 & $\begin{array}{r}(-0.5) \\
-20 \\
\end{array}$ & $\begin{array}{r}(-0.4) \\
-26 \\
\end{array}$ \\
\hline Iron ind. & $\begin{array}{r}(11.9) \\
1302\end{array}$ & $\begin{array}{r}(13.6) \\
3999\end{array}$ & $\begin{array}{r}(11.8) \\
4283\end{array}$ & $\begin{array}{r}(11.2) \\
4987\end{array}$ & $\begin{array}{r}(10.2) \\
4846\end{array}$ & $\left(\begin{array}{r}9.4) \\
4748\end{array}\right)$ & 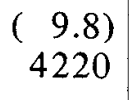 & 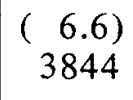 \\
\hline $\begin{array}{l}\text { Chemical and } \\
\text { petro chemi. }\end{array}$ & $\begin{array}{r}(10.9) \\
1723\end{array}$ & $\begin{array}{r}(14.6) \\
3708\end{array}$ & $\begin{array}{r}(21.0) \\
6575\end{array}$ & $\begin{array}{r}(20.7) \\
6593\end{array}$ & $\begin{array}{r}(21.3) \\
6987\end{array}$ & $\begin{array}{r}(21.0) \\
7332\end{array}$ & $\begin{array}{r}(18.3) \\
7105\end{array}$ & $\begin{array}{r}(17.2) \\
7399\end{array}$ \\
\hline $\begin{array}{l}\text { Mashine, metal } \\
\text { manu. }\end{array}$ & $\begin{array}{r}(3.8) \\
7029\end{array}$ & $\begin{array}{r}(7.6) \\
13887\end{array}$ & $\begin{array}{l}(16.6) \\
16660\end{array}$ & $\begin{array}{l}(19.1) \\
16286\end{array}$ & $\begin{array}{l}(20.7) \\
17866\end{array}$ & $\begin{array}{l}(22.4) \\
20138\end{array}$ & $\begin{array}{l}(23.3) \\
22472\end{array}$ & $\begin{array}{l}(24.1) \\
24532\end{array}$ \\
\hline Lumber ind. & $\begin{array}{r}9.1) \\
696\end{array}$ & $\begin{array}{r}(13.9) \\
2587\end{array}$ & $\begin{array}{r}(11.4) \\
246\end{array}$ & $\begin{array}{r}(10.3) \\
1939\end{array}$ & $\begin{array}{r}9.7) \\
1919\end{array}$ & $\mid \begin{array}{r}8.4) \\
1817\end{array}$ & $\left(\begin{array}{r}5.8) \\
1467\end{array}\right.$ & 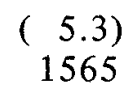 \\
\hline $\begin{array}{l}\text { Materials for } \\
\text { construction }\end{array}$ & $\begin{array}{r}(6.5) \\
473\end{array}$ & $\begin{array}{r}(9.7) \\
1611\end{array}$ & $\begin{array}{r}(9.9) \\
2022\end{array}$ & $\begin{array}{r}(9.1) \\
1884\end{array}$ & $\begin{array}{r}\left(\begin{array}{r}8.2 \\
1774\end{array}\right) \\
\text { (1) }\end{array}$ & $\left(\begin{array}{r}7.0) \\
1601\end{array}\right.$ & 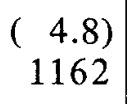 & $\begin{array}{l}(3.6) \\
968\end{array}$ \\
\hline Light ind. & $\begin{array}{r}(24.0) \\
3466\end{array}$ & $\begin{array}{r}(33.9) \\
6962\end{array}$ & $\begin{array}{r}(28.7) \\
7260\end{array}$ & $\begin{array}{r}(28.3) \\
7174\end{array}$ & $\begin{array}{r}(27.4) \\
7361\end{array}$ & $\begin{array}{r}(27.3) \\
7614\end{array}$ & $\begin{array}{r}(26.7) \\
7556\end{array}$ & $\begin{array}{r}(27.3) \\
8177\end{array}$ \\
\hline Foods ind. & $\begin{array}{r}(23.7) \\
4643\end{array}$ & $\begin{array}{r}(25.7) \\
6797\end{array} \mid$ & $\begin{array}{r}(23.9) \\
8564\end{array}$ & $\begin{array}{r}(20.7) \\
7814\end{array}$ & $\begin{array}{r}(20.5) \\
8123\end{array}$ & $\begin{array}{r}(20.8) \\
8520\end{array}$ & $\begin{array}{r}(19.8) \\
8053\end{array}$ & $\begin{array}{l}(18.7) \\
8321\end{array}$ \\
\hline
\end{tabular}

Narodnoe Khoziaistvo USSR in 1980. M., p.505, 506.

Specifically, investments in the oil department have grown from 11.1 billion roubles (9.2\% of total investments) in the 8th Five Year Plan (1966-1970), to 26.2 roubles $(12 \%)$ in the 10 the Five Year Plan. In other words, it has more than doubled in absolute terms, and has grown in relative terms as well. If we add to these investments in the "chemical and petrochemical" department, which grew from 11.0 billion roubles to 22.2 billion roubles, investments in 


\section{OIL PROBLEM IN THE USSR}

the "petroleum and chemical" area nearly equal that of the "machine-metal" industry. Statistics for investments in coal and electric power indicate a relative decrease, while those in natural gas have grown rapidly.

Needless to say, the criterion for "Profit" in Soviet Economics is quite different from that of capitalistic countries. If we follow Janos Kornai (the Hungarian economist), we would say that the situation of an enterprise in the USSR is "soft budget constraint". In fact, however, the state budget constraint is very hard in the USSR. But we may see from the criterion "profit" how every department is efficiently managed. So we can see in Table 6 that the profits of all departments generally came down during 1970's, particularly during the later half of the 70's. Profits for the fuel division which includes petroleum, coal, gas, etc., stagnated in 1978-1980. In the oil extraction department, profits recorded their peak in 1975, then they turned down from stagnation to a decrease. The rate of profit decreased from $16 \%$ to $7.5 \%$, and the high rate of profits such as that of $21.9 \%$ in 1970 could no longer be expected. In the oil refining department, absolute level of profits was still rather high, but the rate of profit has now begun to stagnate. With respect to natural gas, profits continue to grow, but the rate of profit now is only half the level of 1965-1970. The stagnation of the Soviet economic during the latter half of the 1970's is reflected on this table. Except for the "machine-metal" and "light" industries, it is generally recognized that there is a stagnation of profits and of its rate of profit. As to the profitability of coal industry, which was already unprofitable in 1965, it was also unprofitable after 1977.

The implication of the above is very clear. Namely, that notwithstanding the increased investment in oil and co-related departments of the oil industry, the volume of profit and its rate to the investment are contrastingly decreasing year by year. The efficiency of the investment in oil industry is decreasing.

In chapters 1,2 , and 3 , we saw that oil production in the USSR increased markedly, especially after the oil shock. But now we see that its efficiency seems to have come to a turning point. Why has efficiency begun a turndown? It is because the costs of the oil industry are advancing. The following are data which show the efficiency of the investment of the fuel industries made by Soviet scholars. These depend upon Soviet sources. 
HIROMASA NAKAYAMA

Table 7 Factors influenced the change of efficiency at the extracting oil

\begin{tabular}{|l|c||c|c|c|c|c|}
\hline & $\begin{array}{c}\text { Total change } \\
\text { of it }\end{array}$ & $\begin{array}{c}\text { Cost of } \\
\text { oil well }\end{array}$ & $\begin{array}{c}\text { Cost of } \\
\text { construction } \\
\text { of oil well }\end{array}$ & $\begin{array}{c}\text { Productivity } \\
\text { of oil } \\
\text { working well }\end{array}$ & $\begin{array}{c}\text { Coefficient } \\
\text { of } \\
\text { extracting }\end{array}$ & Others \\
\hline Natural gas & -59.3 & -31.6 & -42.3 & +18.2 & +1.1 & -4.7 \\
Oil & -45.7 & -30.4 & -29.2 & +12.6 & +4.4 & -3.1 \\
\hline
\end{tabular}

note (9), p. 64.

These data show the construction of factors which affected the decrease of efficiency of investment on fixed assets between 1971 and 1979. During this period, efficiency decreased $59.3 \%$ in the natural gas extracting industry and $45.7 \%$ in the oil extracting industry. The table shows that the change in the numbers consists of five factors. We can see that the important factors are the cost of oil-wells and their construction. These two factors are the most influential. Conversely, factors increasing efficiency include the productivity of the working oil well itself, that reminds us of growing heavy fixed assets investments in these field. It shows that the quality of the extracting machine itself has become more productive. ${ }^{10}$ We shall return to the technical problem later. Here we can say that the cost of the extraction of oil grew rapidly because in order to reach the oil the search has to be "wider" and "deeper". Of course this is not limited to USSR, rather it is a worldwide phenomenon. For example about $20 \%$ of the world's oil is presently extracted from sea wells. 'Wide" means that the oil wells are farther and farther from oil demanding European Russia. "Deeper", because in the 1950's the average depth of well had to reach about 1350 meters, but this became 2500 meters during the 1970's, and now in the 1980's 3000 meters, and at times even 4000-5000 meters.

Let us look into this situation in greater detail. The oil producing areas have moved to the east. This was first from Baku to the Urals and then to

9. Planovoe Khoziaistvo, 1982-3, V. Burgrov, A. Kuznezov, S. Marushikina.

10. "The density of the mechanized oil extracting wells became greater. In the 11 th Five Year Plan it will be $89 \%$ of all oil extracting wells", Planovoe Khoziaistvo, 1982-10, Y. Andrianov, F. Abubakirov, p. 54. 


\section{OIL PROBLEM IN THE USSR}

western Siberia, and now to eastern Siberia and also to the north. This applies not only to oil but also to mineral extraction in general. For example, only $2.2 \%$ of natural gas was produced east of the Urals in 1965 , but $29.8 \%$ in $1970,39 \%$ in 1973 , and then $46.6 \%$ in 1975 . $35.9 \%$ of coal was produced east of the Urals in 1960 , but this increased to $39.2 \%$ in 1965 to $43.2 \%$ in 1970 , and then to $52.5 \%$ in 1973 . Even the production of iron rose from $11.3 \%$ in 1960 to $15.1 \%$ in 1973 in the east. Parallel to these raw materials, the oil producing areas moved to the east. Only $7.4 \%$ of oil was produced east of the Urals in 1960 , but this grew to $18.1 \%$ in 1970 , to $30.1 \%$ in 1973. ${ }^{11}$ And then 39\% in 1975 (in western Siberia 30.2\%) and finally in 1980 , in the western Siberia alone $51.8 \%$ of USSR oil is produced.

One of the most difficult problems is that "the place of consumption of the oil is geographically often separated from the place of production, usually from 2-4 thousands kilometers". ${ }^{12}$ It frollows from this that, "the distance of the oil well from the main producing economic center, wide extent, in sufficient rail-way networks; these factors limit the use of transportation." In the structure of the price of goods, transportation costs occupy a rather large percentage. For example, transportation of building materials in Tyumeni state along the Obi river, accounts for $57 \%$ of the cost in the building and construction of an oil base. ${ }^{13}$ Especially in the far northern areas, from which precious materials such as gold are transported, such costs are growing. The most bulky materials such as lumber must be transported by water way and the location of extraction is determined by access to such natural means of transport. An exception is of the transportation oil and natural gas, where new sturdy and costly pipe-lines must be constructed. In order to accomplish this, local, social, and industrial infrastructures must be constructed. But their efficiency is not so high, because there are only small number of firms which can maintain services and repair equipment of fundamental products. There is also the limitation in the raw material base of the local district because of a lack of agriculture and livestock industries. A high concentration of labour leads to a high cost of the products because of high rates of

11. Hirosama Nakayama, Expanding Socialism in USSR (J)., 1976, p. 236.

12. Planovoe Khoziaistvo, 1982-4, Y. Mazover, T. Makarora, p. 61.

13. Voprosyi Ekonomiki, 1981-8, A. Khaityn, p. 35. 


\section{HIROMASA NAKAYAMA}

Table 8

\begin{tabular}{|l|c|c|c|}
\hline & Marsh & Lake & Swamp \\
\hline Samotroie & 60 & 15 & 4 \\
Yschi-baruichiskoe & 50 & 12 & 67 \\
Mamontob & 40 & 6 & 9 \\
Variegansk & 37 & 35 & - \\
Pravdinsk & 40 & 3 & 10 \\
\hline
\end{tabular}

wage and of transportation. There is further lack of harbors. Additional investment for rail way and automobile construction costs are 2-3 times that of the European USSR. The construction of airports because of the complexity and the severity of the climate cause costs to run high. Because modern Russian industries have developed along the northern and eastern periphery under difficult natural and climatic conditions, and because $76 \%$ of the demand for their products is in the European and Ural sectors, the expenditures for extraction and transportation have grown more and more, namely by billions of roubles more every year. ${ }^{14}$ In 1980 more than 300 million tons was transported through oil pipe-line from Western Siberia, over an average distance which exceeded 1000 kilometers. The productivity of gas transporting pipe grew. To build the base for oil transportation, material in the amount of more than 20 million tons must be transported by the ordinary train every year. For the laying of one large gas pipe-line from the Tyumeni northern area, about 5 million tons of material is needed. Natural conditions are a major concern since many of the oil producing areas of Western Siberia are situated on marsh, lake, and swamp lands. The breakdown can be seen in Table $8 .^{15}$

We can readily understand the difficulty in developing towns for human habitation in these producing areas. At this point we shall examine in more detail a gas producing base in western Siberia during the 1970's. It developed along the River Obi, recently $4 / 5$ of the by-products of natural gas have been produced from its northern part. (500-600 kilometers) A "very abnormal

14. Planovoe Khoziaistvo, 1981-1, A. Lalayanz.

15. Voprosy Ekonomiki, 1981-8, A. Khaitun, p. 37. 


\section{OIL PROBLEM IN THE USSR}

Table 9

\begin{tabular}{|l|c|c|c|c|c|}
\hline & $\begin{array}{c}\text { All kinds } \\
\text { of sectors }\end{array}$ & Oil ind. & Gas ind. & Geology & Construction \\
\hline $\begin{array}{l}\text { Fond of apartment } \\
\text { (M }{ }^{2} / \text { person) }\end{array}$ & 10.6 & 7.8 & 5.5 & 7.3 & 5.8 \\
$\begin{array}{l}\text { Childrens institutions } \\
\text { (\% to demand) }\end{array}$ & 70 & 43 & 50.8 & 39 & 40.8 \\
$\begin{array}{l}\text { Guarantee of schools } \\
\text { (\% to demand) }\end{array}$ & 84.5 & 73 & 51.1 & 36 & - \\
\hline
\end{tabular}

character of carrying the oil firms in the western Siberia is that the oil had to be extracted not on land but on marshes at first." 16 In the north part of western Siberia there is much peat and generally speaking, oil and gas can usually be found in conjunction with peat, "so it is very difficult to build towns and workers' residences around these places. And it is also said that the elemental deficit of constructing towns in traditional forms in the western Siberia is decentralization of many small towns which are almost simultaneously built. Therefore the productivity of the construction of apartments is very inefficient." "In 1978, the standard of security of living services in this area was $86 \%$ of the average standard of the European parts of USSR, $88 \%$ of the living fond, $22 \%$ of the density of the land transport network, $5 \%$ of the electric wire." See the Table 9.17

"Widening the extraction of oil, gas, and iron ore from the sea floor greatly increases the additional investment. For example, in 1960, 2 roubles of investment were necessary for each additional rouble of raw material. This grew in 1970 to 3 roubles and in 1980 to about 4 roubles. And may go to 56 roubles in the very near future." 18 We can also see from the papers of Russian scholars, that "the cost for constructing a natural gas base in Komi ASSR is 1.5-1.8 times greater than the average for Russia, while in Northern Tyumeny, it is 2.2-3.5 times, and in the Northern Krasnoyarusk it is 2.5-3.0 times. Generally, the standard value of construction budgets in the north is 2.5-7.5 times higher than the central districts." Almost all additional produc-

16. Planovoe Khoziaistvo, 1980-8, Orlov.

17. Voprosy Ekonomiki, 1981-8, A. Khaitun, p. 44.

18. Voprosy Ekonomiki, 1982-12, N. Feiteliman, p. 65. 


\section{HIROMASA NAKAYAMA}

tion of oil and gas of the 11th and the 12th Five Year Plan will be made in western Siberia, where many kinds of raw materials are concentrated. In the northern sections of Siberia the cost of construction is 2-3 times higher than that for the European areas, 5-6 times higher for road construction, 1.52.0 times higher for gas pipe-lines. ${ }^{19}$ Concerning these pipelines, it is said that "to construct 1000 kilometers of gas pipeline at a new location where there is no railway requires 700 thousands tons of metal pipes."20 It is further necessary to fly three hundred highly skilled specialists from other producing sectors to the new locations with harsh natural conditions. But such costs can not be avoided for the 11th Five Year Plan calls for 630 billion cub. meters of natural gas which are supposedly to be extracted in 1985375 billion cub. meters $(56 \%)$ of which is to be extracted in western Siberia under severe natural conditions.

We now return to the technical problems of extraction. Together with other factors such as climatic conditions, Dr. Sh. Rosenfeld has pointed out that one reason for the rise in the cost of raw materials is the depth at which they must be extracted. He has written "in modern times, most raw materials were extracted at a relatively shallow depth in the earth's crust (generally about 700-800 meters). But only a small part of the earth's wealth is found in this part of the crust. If we wish to extract materials at a 30 meter depth, it costs 3 times more than on the surface of the earth. If it is at a depth of 300 meters, costs are 12 times greater."21 Of course costs differ according to the materials to be extracted. In the case of natural gas, when the mine deepens 10 meters, cost of the fixed fund grows $1.1 \%$ without additional extraction. The depth of coal mines grew about 1.6 times from 1960 to 1977. Iron ore is being extracted at depths of 1200-1500 meters, with bauxite from the norther Urals being extracted at 1500 meters. In general as the mines grow deeper and deeper, poorer mines must be exploited. During the 19 th century, lead and zinc were extracted from ores of $8-10 \%$ concentration. But after the Second World War it was thought that 5-8\% standard concentration was acceptable, and during the 10th Five Year Plan (1976-

19. Op. cit., p. 66.

20. Voprosy Ekonomiki, 1983-4, V.,Voznyak, p. 75.

21. Voprosy Ekonomiki, 1982-2, p. 32., Sh. Rosenfeld. 


\section{OIL PROBLEM IN THE USSR}

1980), 1.5-2.7\% became the standard. The standard of raw copper met with similar declines, from $5-6 \%$ to $0.8-1.5 \%$, with Iron also declining between 1950 and 1980 to $14.9 \%$. Under such circumstances, to succeed in stabilizing the level of extraction, the technique is to use pressurized water, that is called in Russian "zakachika". At the current level of technology, the complete extraction of raw materials has not yet been developed. For example, losses of usable raw materials during extraction reach about $1 / 4$. Loss during the process of dressing ores, manufacturing, and working with them, reaches 20 to $50 \%$ of the starting total. Thus usually only $10-20 \%$ of raw materials are used, and only in special cases up to $50-70 \% .^{22}$ Another researcher writes that the used energy raw materials are $43 \%$ in 1980 (almost at the same level to other countries). Conversely, the percentage of produced energy are lossed when they are used; that equals about 900 million ton hypothetical unit. Of course, these losses occur not only because of idleness and inefficient management in the using process, but also because of the not very high technical level of manufacturing, transporting, and using process of fuel-energy industries. At the same time, the technical level and structure of the equipment of using fuels is low. ${ }^{23}$ Plans are to decrease the loss of the electric energy through transportation by 7 billion KWh (production of 1981 is 1321 billion KWh). ${ }^{24}$ Of course calculations of percentages of lost materials are different in each case. Dr. Rosenfeld maintains that by using improved technology for extraction raw materials, $40 \%$ more oil can be extracted; which could not be extracted before by the traditional methods. Generally speaking, around $1 / 3$ of the oil is extracted by the natural pressure method, but under new methods, it has become possible to extract $70-80 \%$ of the oil. It must also be considered about the oil loss and the natural gas loss problem. To avoid this loss a more complex and efficient method of extraction must be used. ${ }^{25}$ The technical methods of oil extraction used in the USSR are artificial pressure. The so called "zakachika" method which accounts for $85 \%$ of oil extraction, grew six times from 1960 to 1980 . The extraction of oil in 1960 was

22. Op. cit., p. 33.

23. Planovoe Khoziaistvo, 1981-1, A. Lalayanz, p. 34.

24. Planovoe Khoziaistvo, 1981-9, A. Pyatkin, A. Troitzky, p. 57.

25. Voprosy Ekonomiki, 1982-2, p. 39-40. 
1.3 cub. m. and in 1980 it was already 2 cub. m., moreover it was much water-containing. The oil was containing water over $50 \%$ in 1977 , and even $90 \%$ in some places. ${ }^{26}$

Finally we must touch upon the problem of the oil laborers. This problem together with the problem of the local population in Siberia is very complex, for the area has a minus population growth as a result of the great outflow of people from the area. But this is only a general trend. For example in Tyumeni, the oil area, $80 \%$ of the coming laborer is so called labor-possible -people and about half of them are between 16-30 years old, and one fifth are 30-39 year old. This is a very young population. In the 25-29 year range men outnumber women. A further difficult problem is to keep these young people in western Siberia. The most important factors of this problem are the social-living conditions and not wages. $^{27}$ It often happens of course that the laborer works in this kind of difficult location without the accompaniment of his family. ${ }^{28}$

These are not all of the reasons that provide us perspectives for understanding the decreasing of oil production in the USSR for the foreseable future. But these are sufficient reasons for us to understand the difficulties that the oil industry in the USSR is experiencing.

But I welcome the decreasing of oil production in the USSR. Because, it is said that it took 25 billion years for oil to be created, human beings are now consuming this oil in only one hundred years. So we must be more modest in consuming oil. In this sense, the oil problem in the USSR is not only that of the USSR, but also of the entire world, of all humankind.

26. Voprosy Ekonomiki, 1982-12, p. 67.

27. Planovoe Khoziaistvo, 1984-1, A. Ananiev, A. Shilin, p. 94.

28. Planovoe Khoziaistvo, 1984-1, p. 97. 